\title{
DA EXECUÇÃO DA DÍVIDA PROPTER REM: EXECUÇÃO DE TÍTULO EXTRAJUDICIAL DE CRÉDITO CONDOMINIAL PARA A QUITAÇÃO DE ÔNUS POR ELE PRÓPRIO GERADO
}

\author{
Pamella Karoline Gomes* \\ Professora Mestra Daniela Pozza Batista**
}

\section{RESUMO}

Trata-se de discussões acerca das cobranças de cotas condominiais, como essa dívida é gerada e como pode ser cobrada. Demonstra-se que a partir do Novo Código de Processo Civil, buscou-se tornar a cobrança mais célere em um aspecto geral, a fim de resguardar o Condomínio e os condôminos adimplentes. Ressalta-se que para tanto se faz necessário examinar pontos específicos, como: o tipo de débito em que a dívida condominial se enquadra no caso concreto, bem como, a ação adequada para o ingresso da cobrança e a respectiva execução dentro de parâmetros estabelecidos legalmente. Deste modo, é de suma importância que sejam verificados os requisitos basilares como: quem responde por essa dívida e seus encargos, de forma que ao buscar o direito de recebimento do crédito o condomínio credor não tenha prejuízos irreversíveis. Esse cuidado se dá mediante a divergência nos julgados desta matéria que acabam por trazer insegurança tanto para os credores quanto os possíveis devedores desse débito, questões essas carentes de uniformização. Assim, buscou- se entender o tipo de direito sobre o imóvel que faz parte de um condomínio, como se dá a cobrança das cotas condominiais e, em caso extremo, de levar o imóvel a leilão decorrente da dívida, como isto pode ou deve ser feito.

Palavras-chave: Débito de condomínio. Dívida Propter rem. Título Executivo Extrajudicial. Penhora de imóvel.

\section{EXECUTION OF PROPTER REM OBLIGATION: EXECUTION OF CONDOMINIUM QUOTAS EXTRAJUDICIAL TITLES FOR COLLECTION OF THE ONUS DEVELOPED BY THE CONDOMINIUM ITSELF}

\section{ABSTRACT}

These are discussions about the collection of condominium quotas, how this debt develops and how it can be collected. It has been shown that the New

* Bacharel em Direito pela Universidade Metodista de São Paulo. E-mail: pamellakarolineg@hotmail.com.

** Mestre em Direitos Difusos e Coletivos pela Universidade Metropolitana de Santos - UNIMES. Especialista em Direito Processual pela Universidade Paulista - UNIP. Advogada. Professora Universitária e Coordenadora do Escritório de Assistência Judiciária. 
Code of Civil Procedure seeks to make the collection faster in an overall aspect, in order to protect the Condominium and its compliant members. It is noteworthy that for this purpose it is necessary to verify specific aspects, such as in which type of financial obligation the Condominium debt fits in the concrete case: the appropriate action to fill for collection and its execution within legal parameters. Accordingly, it is of utmost importance to check the basic requirements, for example who is accountable for this debt and its charges. Therefore, keeping the creditor Condominium from irreversible losses once seeking the right to collect credit. This care is necessary due to judgment discrepancies in this matter, which bring insecurity for both creditors and possible debtors of the financial obligation. These issues lack standardization. Thus, it is sought to understand the type of right existent over the property that is part of a Condominium. In addition, how the condominium fees are collected and in the extreme case of taking the property up for auction due to the debt, how this matter could or should be handled.

Keywords: Condominium fees. Propter rem obligation. Extrajudicial Executive Title. Property Lien.

\section{INTRODUÇÃO}

O tema aborda o conflito no Poder Judiciário com relação à responsabilidade de débitos propter rem, em que os casos analisados são similares e/ou idênticos, com a mesma finalidade, e que ao final são decididos em sentidos contraditórios gerando insegurança jurídica.

De início, busca-se esclarecer a natureza da dívida condominial, descrever o condomínio edilício e o título executivo extrajudicial, de cujo rol as despesas condominiais passaram a fazer parte e o Código Civil dispõe que, quando é transferido o bem, a obrigação o segue não podendo o adquirente recusar-se a assumir tal ônus.

No caso de despesas condominiais, trata-se de obrigações que acompanham o bem imóvel, especificando o Código Civil que, aquele que detém a propriedade plena ou até mesmo a posse do objeto deverá arcar com seus encargos, mesmoque a dívida exista antes da transferência de propriedade.

Ante a não formalização da transferência da propriedade no órgão competente, iniciada pelo instrumento particular de venda e compra, muitas vezes por questões de valores, são acarretados prejuízos tanto àquele que transmite a propriedade quanto àquele que a adquire, uma vez que, em diversas situações, a transferência do bem imóvel é feita com dívidas, e o imóvel sempre poderá vir a responder.

Com essa transferência não registrada entre os particulares (vendedor e comprador), caso o bem imóvel obtenha dívidas, a penhora do bem para o recebimento de qualquer crédito pode restar prejudicada, vez que "não se sabe" de quem cobrar, ainda mais quando as decisões judiciais são oponentes quanto ao debate, e até hoje, existe conflito em todas as instâncias.

\section{DO DIREITO DAS COISAS}

Este ramo do Direito Civil visa regulamentar a relação entre as pessoas e as coisas físicas, bens materiais, a fim de se fazer possível o efetivo domínio das coisas que versam sobre aquisição, exercício, conservação e perda do poder sobre tais 
bens. Segundo a definição de Clóvis Beviláqua (1916, apud GONÇALVES, 2012, p. 13), o direito das coisas é: “o complexo de normas regulamentadoras das relações jurídicas referente a coisas suscetíveis de apropriação pelo homem. Tais coisas são, ordinariamente, do mundo físico, porque sobre elas é que é possível exercer o poder do domínio".

Até há pouco tempo, o direito das coisas era exclusivo do direito privado, pois havia um sistema hereditário para garantir o domínio em uma determinada família, de forma que a propriedade não perdesse seu poder no sistema político, assegurando que pertencessem sempre à classe burguesa. Somente em meados do século XX é que se sustentou a ideia de função social do bem comum da sociedade, de forma que o conceito de propriedade e direito das coisas foi influenciado por este pensamento, como disposto pela Constituição Federal, em seu artigo $5^{\circ}$, inciso XXII. Destaca Gonçalves:

A preponderância do interesse público sobre o privado se manifesta em todos os setores do direito, influindo decisivamente na formação do perfil atual do direito de propriedade, que deixou de apresentar as características de direito absoluto e ilimitado para se transformar em um direito de finalidade social. (GONÇALVES, 2018, p. 18).

O direito das coisas, além do Código Civil, também está regulado em outras leis especiais, como a alienação fiduciária, os loteamentos, a propriedade horizontal, etc., de modo a regularizar o direito das coisas de forma separada, sendo a posse (art. 1.196 a 1.203), os direitos reais (art. 1.225 a 1.227) e o direito de propriedade (art. 1.228 a 1.368-B), para o melhor desdobramento dos direitos propriamente ditos. Entende Cassettari (2018, p. 355) que: “Direito real é a relação jurídica em virtude da qual o titular pode retirar da coisa, de modo exclusivo e contra todos, as utilidades que ela é capaz de produzir. Traduz apropriação de riquezas e tem por objeto uma coisa material."

Um exemplo sobre o direito real é a hipoteca, garantia que recai na maioria das vezes sobre bens imóveis, e assim esses direitos reais dão ao credor o direito de executar contra quem esteja com o bem. "Assim, não importa se o bem foi transferido a terceiro; este também o perderá, mesmo que o tenha adquirido de boa-fé." (TARTUCE, 2019, p. 47).

Os direitos reais são regidos pelo princípio da publicidade - tradição e registro; por exemplo, um carro onde há tradição no momento da entrega das chaves e o registro no momento da venda do veículo de forma devidamente documentada.

Direito real de aquisição é o direito que comprador do imóvel possui, isto porque a compra e a venda devem ser registradas em cartório, onde as partes assumem a declaração de vontade do compromisso pactuado, podendo ocorrer também o direito real de garantia, nos casos de hipoteca, penhor ou anticrese (quando é recebido um bem em troca de pagamento de uma dívida).

Em direitos pessoais, as relações jurídicas são entre duas ou mais pessoas, sendo credor e devedor. É considerado o princípio da autonomia privada, havendo liberdade de negociação entre as partes, de modo que, em necessidade de execução, são os bens do devedor que respondem, e não a coisa. 
Em suma, os direitos reais têm caráter permanente, normalmente em propriedades; já os direitos pessoais, em regra, caráter transitório, devido àliberdade dos contratos entre as partes.

Além das elencadas anteriormente temos a categoria híbrida, pois a obrigação propter rem é uma espécie jurídica que fica entre o direito real e o pessoal. Propter rem significa "por causa da coisa", "obrigação que segue", de forma que o direito e/ ou obrigação segue a coisa, independente de quem detenha o título. Nas palavras de Mello: "a obrigação propter rem é a obrigação de um direito pessoal que nasce de um direito real". (2017, p. 44).

No entendimento de Cassettari: “As obrigações propter rem são aquelas que nascem independentemente da vontade do devedor, por ser ele titular de um direito real, motivo pelo qual elas seguem e recaem sobre a coisa". (2018, p. 142).

Como forma de visualizar melhor, tem-se como um dos exemplos o condomínio. A cota condominial é derivada da fração ideal de cada condômino, e a garantia de pagamento de cada cota é a própria fração ideal (o bem imóvel), recaindo tal obrigação por força de um direito real. De modo que o condômino (estando ele na condição de proprietário ou possuidor) é obrigado a concorrer para as despesas de conservação, suportando o ônus a que estiver sujeito na proporção de sua fração ideal.

A posse pode ser adquirida com título, quando há documentação que comprove o domínio, como, por exemplo, o contrato de locação, presumindo-se por si só a boa-fé, ou sem título, quando não há demonstrada a transmissão de posse.

O direito de propriedade, por outro lado, é o mais importante dos direitos reais, pois submete a coisa ao titular do domínio em todos seus serviços, sendo esta o direito de gozar, usar e dispor de bens em sua totalidade, conforme disposição no art.1.228 do Código Civil. É assegurado ainda pela Constituição Federal, art. $5^{\circ}$, incisos XXII e XXIII, devendo ser exercido em consonância com suas finalidades econômicas e sociais, preservados em conformidade com o que estabelece a lei.

\section{DO CONDOMÍNIO}

O condomínio, em suma, ocorre quando duas ou mais pessoas são proprietárias de uma determinada coisa. Uma cotitularidade de direitos sobre uma mesma coisa indivisa seja móvel ou imóvel. Essas pessoas são denominadas condôminos (as).

Ocorre o condomínio ordinário quando a mesma coisa pertence a mais de uma pessoa, cabendo a cada uma delas igual direito, idealmente, sobre o todo e cada uma das partes. Nesse caso, a coisa indivisa é distribuída em frações ideais, para consortes diversos. (CASSETTARI, 2018, p. 398).

Para Tartuce, "verifica-se a existência do condomínio quando mais de uma pessoa tem a propriedade sobre determinado bem, seja ele móvel ou imóvel." (2019, p. 474).

No condomínio geral, os proprietários são donos de tudo, sem qualquer exclusividade, podendo os condôminos utilizarem e modificarem, pode ser extinto ou vendido, caso os proprietários/condôminos estejam de comum acordo. Via de re- 
gra, as coisas pertencem a uma só pessoa, mas o condomínio é exceção ao princípio fundamental da propriedade e ao princípio da exclusividade. (MELLO, 2012, p. 3).

A fim de reduzir o risco de conflitos entre os condôminos, o Código Civil estabeleceu algumas regras, dividindo-as em modalidades, quais sejam: i) Condomínio necessário ou legal, ii) Condomínio voluntário ou convencional, iii) Condomínio de fato, e iv) Condomínio edilício ou especial.

De forma sucinta, esclarece que o Condomínio necessário ou legal é aquele imposto por lei, e independe da vontade das partes, sendo estabelecido por muros e paredes divisórias, enquanto o Condomínio voluntário ou convencional ocorre conforme a vontade das partes/condôminos, se tratando de autonomia privada, por ato inter vivos. Ocorre em regime de incorporação imobiliária para a construção em condomínio, presumindo que a propriedade será dividida em partes iguais, caso o instrumento de sua instituição nada mencione.

O Condomínio de fato não é estabelecido por lei ou por convenção. Esta modalidade pode ser facilmente confundida com o Condomínio Edilício, pois o primeiro momento é para manutenção das propriedades; porém, no caso do Condomínio de fato é comum ocorrer nos casos de associação de moradores, onde estes cuidam da área pública de uso comum do povo.

Condomínio edilício ou especial é disciplinado pela Lei 4.951/64, contendo dois títulos: I - Do condomínio e II - Das incorporações, qual o primeiro foi incorporado ao Código Civil de 2002, de forma inovadora.

O Condomínio edilício também é conhecido como: condomínio em plano horizontal, propriedade horizontal, condomínio sui generis ${ }^{1}$, Condomínio por andares ou em edifício de andares e diferente do Condomínio voluntário ou convencional. O Condomínio edilício nada mais é que condomínio em edifício (prédios residenciais ou comerciais), onde cada condômino possui parte exclusiva da coisa.

O condomínio em geral pode ocorrer em coisas imóveis e móveis, porém o Condomínio edilício só ocorre em coisa imóvel, coexistindo partes comuns e partes exclusivas e em um edifício residencial. A parte exclusiva de cada condômino é seu próprio apartamento, somado mais uma parte da fração ideal nas partes comuns que são elevadores, portaria, jardins, salões de festas e piscina, por exemplo.

No Código Civil, são demonstradas as especificações para a instituição do condomínio edilício, sua conservação, manutenção, administração, direitos e deveres dos condôminos e em casos específicos a extinção.

O Condomínio edilício é instituído por ato entre vivos ou testamento, registrando em Cartório de Registro de Imóveis, devendo constar naquele ato, além do disposto em lei especial, a discriminação e individualização das unidades de propriedade exclusiva, estremadas uma das outras e das partes comuns; a determinação da fração ideal atribuída a cada unidade, relativamente ao terreno e partes comuns; e o fim a que as unidades se destinam. (BRASIL, Código Civil, art. 1.332, 2002).

1 DICIO: sui generis significa: Único; que não se parece com nenhum outro; único em seu gênero: expressão sui generis; inteligência sui generis. Disponível em: https://www.dicio.com.br/sui-generis/ 
De acordo com o art. 1.335, inciso I, do Código Civil, os condôminos poderão usar, fruir e livremente dispor de seus apartamentos, bem como usar as partes comuns. Estando quite com as contribuições condominiais pode participar e votar nas assembleias e, do mesmo modo, especifica-se os direitos dos condôminos por um rol dos deveres, para que não haja utilização de forma prejudicial à edificação, para que uns não prejudiquem o sossego e a segurança dos demais condôminos, incumbindo-lhes ainda a contribuição para as despesas na proporção de suas frações ideais, sob pena de juros moratórios e multa sobre o débito.

Apesar da ausência de personalidade jurídica, o Condomínio edilício possui personalidade judiciária, podendo ser representado por um síndico ou um administrador, trazida pela Lei 13.105/2015, art. 75, inciso XI, e que não foi elencado ao rol do art. 44 do Código Civil, qual específica as pessoas jurídicas de direito privado, qual o Condomínio edilício não se enquadra, de forma que não se pode denominar empresa.

Apesar de esta questão ser muito discutida devido ao fato de o Condomínio edilício possuir CNPJ (Cadastro Nacional de Pessoas Jurídicas), sua natureza é considerada híbrida ou anômala, isto porque há combinação harmônica entre propriedade privada e coletiva.

O cadastro necessário de CNPJ é apenas para que o condomínio, devidamente representado por seu síndico, possa atestar a existência e possibilidade de o condomínio manter relações com terceiros, como, por exemplo, pagamento de funcionários, de prestações de serviços, compra de produtos para manutenção própria, bem como estar legitimado para atuar em juízo de forma ativa e passiva. Sendo assim, condomínio não é uma pessoa jurídica, não existindo, pois, um ente dotado de personalidade. Na verdade, o condomínio constitui modalidade especial de propriedade, direito real por excelência. (MELLO, 2012, p. 15). (grifo nosso).

Para o bom funcionamento do Condomínio edilício, a lei determina que em forma de assembleia seja eleito um síndico, ou um subsíndico, para responder na ausência do primeiro, que representará o condomínio. Emitirá a vontade em nome dos demais, entre diversas atribuições, tais como a de cobrar dos condôminos as suas contribuições, bem como impor e cobrar multas devidas. (BRASIL Código Civil, art. 1.348, VII, 2002).

A administração do condomínio, em geral, é composta pelo síndico, subsíndico (quando houver), conselho fiscal, a assembleia (reunião de todos ou da maioria dos condôminos) e, em alguns momentos, a administradora de condomínios.

Uma das partes mais importantes na administração do condomínio é a cota ou taxa condominial, certo ser impossível manter o edifício sem seu efetivo pagamento, pois a cota ou taxa condominial nada mais é que rateio das despesas mensais ou não do condomínio, como água, luz, folha de pagamento dos funcionários, manutenção e conservação de elevadores e obras periódicas nas áreas comuns, por exemplo.

A obrigação do pagamento das cotas condominiais é assegurada pelo art. 1.336, I, do Código Civil, sob pena de juros, multa e em medidas mais severas as 
ações judiciais, de modo que cada condômino deverá pagar de acordo com sua fração ideal, condição determinada por lei e convenção condominial, suprindo assim apenas as despesas coletivas.

O valor da cota condominial deverá ser definido em assembleia geral, havendo votação dos condôminos, e são divididas em: (i) Despesas ordinárias, que englobam os gastos com as despesas básicas (água, luz e gás nas áreas comuns, salários e contribuições de funcionários, manutenção e conservação de equipamentos no uso comum, etc.); e (ii) Despesas extraordinárias, quais são para cobrir os gastos não rotineiros (pintura de fachada, instalação e iluminação na área comum, indenizações trabalhistas, instalações com equipamentos de segurança, ou lazer, decorações, constituição de fundo de reserva, etc.).

Um dos grandes problemas nos Condomínios edilícios é a inadimplência e, como referido anteriormente, sem a contribuição e pagamento das cotas condominiais é quase impossível manter o condomínio.

O Condomínio edilício, por natureza, não possui fins lucrativos, isto porque o legislador não conferiu à referida propriedade a capacidade jurídica para tanto, sendo que o condomínio depende, exclusivamente, do pontual pagamento do rateio mensal de seus condôminos a fim de que possa cumprir com suas obrigações, tanto perante aos condôminos como a terceiros, e proporcionar comodidade e segurança aos seus moradores.

As contribuições condominiais não se destinam a satisfazer um financiamento, mas à própria despesa do condomínio, antecipada ou concomitantemente com sua realização, e quando um condômino deixa de honrar com essa obrigação a cota parte deste é dividida entre os adimplentes, o que não significa que medidas não poderão ser tomadas.

Existem diversos motivos para que um condômino se torne inadimplente, na maioria dos casos o financeiro, outros por preferência ou prioridade a demais despesas, e em muitos casos ausência de informação ou problemas com a documentação e transferência do imóvel. Entretanto, nenhum dos possíveis motivos elencados exime o condômino de honrar tal obrigação, como decidido pelo Tribunal de Justiça de São Paulo:

Despesas condominiais. Cobrança. Inadimplemento que restou incontroverso. Dificuldades financeiras dos devedores que, conquanto lamentáveis, não constituem fator de força maior ou caso fortuito. Obrigação "propter rem". [...] Sentença mantida. Recursos improvidos, com majoração da verba advocatícia. (TJSP; Apelação Cível 101799775.2015.8.26.0576; Relator (a): Bonilha Filho; Órgão Julgador: 26a Câmara de Direito Privado; Foro de São José do Rio Preto - $4^{\mathrm{a}}$ Vara Cível; Data do Julgamento: 19/04/2018; Data de Registro: 19/04/2018) (grifo nosso).

Nesta mesma linha:

APELAÇÃO - COBRANÇA DE DESPESAS CONDOMINIAIS Inadimplemento incontroverso - Dificuldades financeiras da devedora 
que, conquanto lamentáveis, não constituem fator de força maior - Circunstância que não é suficiente para exonerar a requerida do dever de cumprimento das obrigações perante o condomínio - Obrigação propter rem - Precedentes desta Corte - SENTENÇA MANTIDA - RECURSO DESPROVIDO. (TJSP; Apelação Cível 1007023-74.2014.8.26.0006; Relator (a): AZUMA NISHI; Órgão Julgador: $37^{a}$ Câmara Extraordinária de Direito Privado; Foro Regional VI - Penha de França - $4^{\text {a }}$ Vara Cível; Data do Julgamento: 05/02/2018; Data de Registro: 05/02/2018) (grifo nosso).

Vejamos assim que ambos os julgados afirmam que, apesar de lamentável a situação financeira do devedor, este motivo não serve para que deixe de honrar com os débitos condominiais.

Nesta esteira, conceitua Gomes que "propter rem" é o novo titular assumir a obrigação: "Quem quer que seja proprietário da coisa, ou titular de outro direito real, é, ipso facto, devedor da prestação. A obrigação está vinculada à coisa". (GOMES, ORLANDO APUD RIZZARDO, ARNALDO, 2017, p. 279).

Muitos dos condôminos já adquirem o apartamento com débitos anteriores e são responsabilizados. Isto ocorre para que o bem seja resguardado, afinal, seja quem for o proprietário, devido à natureza do bem, este responde por seus débitos, conforme aludido por Moraes:

Ora, assim, é bom alvitre que aquele que vier a adquirir uma unidade condominial tenha o cuidado de verificar a existência de débitos anteriores, existência de multas, já que o adquirente da unidade condominial responde pelos débitos anteriores relativos ao condomínio, inclusive multas e juros moratórios. (MELLO, CLEYSON DE MORAES, 2012, p. 83). (grifo nosso).

Na mesma esteira, é afirmado por Tartuce que o novo adquirente responde pelas dívidas anteriores à aquisição:

[...] a obrigação do proprietário de pagar as despesas de condomínio, o que pode ser retirado do art. 1.345 do atual Código Civil, pelo qual o proprietário da unidade condominial em edifícios responde pelas dívidas anteriores que gravam a coisa". (TARTUCE, 2019, p. 51). (grifo nosso).

Isto posto, se esclarece ainda que quando a natureza é propter rem, o atual proprietário não poderá se eximir dos encargos anteriores, tomando para si a responsabilidade dos débitos, vez que, nas palavras de Rizzardo: “a obrigação segue a coisa e não o sujeito" (RIZZARDO, 2017, p. 280), condição imposta também aos promitentes compradores de acordo com o Código Civil de 2002, art. 1.334, § $2^{\circ}$. Entretanto, observa-se que, para comprovação de titularidade de bens imóveis, é necessário que haja a tradição da venda em registro do imóvel em cartório competente.

A hipótese de cobrança das despesas condominiais de natureza propter rem serem cobradas na condição do art. 1.334, $\S 2^{\circ}$ do Código Civil poderá ocorrer desde 
que o condomínio tenha ciência da venda, caso contrário, mantém-se responsável aquele que figurar no documento formal (Certidão de Registro do imóvel).

De modo que, sem a anuência do condomínio o proprietário que constar na matrícula do imóvel (apartamento), mesmo que realizada venda via contrato de compra e venda (contrato de gaveta), deverá arcar com o ônus dos débitos, conforme entendido pelo Tribunal de Justiça de São Paulo:

[...] Unidade condominial que foi objeto de compra e venda a terceiro. Ausência de prova de comunicação formal e inequívoca ao Condomínio, antes da propositura da ação de cobrança. Obrigação propter rem. Prevalecimento do interesse da comunidade, presumivelmente pagante e majoritária, em receber os recursos óbvios e necessários à sua sobrevivência. Débito incontroverso. Nega-se provimento ao recurso da requerida. (TJSP; Apelação Cível 1015733-12.2019.8.26.0361; Relator (a): Campos Petroni; Órgão Julgador: $27^{\mathrm{a}}$ Câmara de Direito Privado; Foro de Mogi das Cruzes - $2^{a}$ Vara Cível; Data do Julgamento: 07/05/2020; Data de Registro: 07/05/2020) (grifo nosso).

No julgado supracitado, trata-se de ação de cobrança proposta pelo condomínio em face do proprietário da unidade devedora, a fim de receber o pagamento pelas cotas condominiais em atraso. Mesmo anunciado nos autos que o imóvel fora vendido, ante a ausência de ciência da venda do apartamento ao condomínio prevalece a informação de proprietário daquele que tem a propriedade registrada em cartório.

Conforme estipulado pelo Código Civil de 2002, art. 1.336, inciso I, é dever do condômino "contribuir para as despesas do condomínio na proporção das suas frações, salvo disposição em contrário da convenção", de forma que é imposta penalidade de juros moratórios de $1 \%$ ao mês e multa de $2 \%$ sobre o total do débito, quando não for estipulado pela convenção condominial.

Quando não houver especificado em convenção condominial a previsão dos juros moratórios, de acordo com o art. 406 do mesmo código, a taxa a ser utilizada deverá ser a mesma que estiver em vigor para a mora do pagamento de impostos devidos à Fazenda Nacional.

Em caso de inadimplência, o síndico/administrador, representante legal do condomínio, poderá tentar resolver com: (i) notificações, (ii) tentativa de acordo extrajudicial, (iii) protestar a dívida, de modo que o nome do inadimplente seja enviado aos órgãos de proteção ao crédito ou (iv) ingressar com ação judicial.

Salienta-se que mesmo com as mudanças no Código de Processo Civil a respeito da cobrança de cotas condominiais, o condomínio pode escolher qual via processual pretende utilizar.

Com a natureza de título executivo extrajudicial dada às cotas condominiais, entendeu-se na transição da Lei 13.105/2015 que somente poderiam ser ajuizadas ações de execução, não mais a ação de cobrança (conhecimento) como era feito na atuação do CPC/73, de modo que ações de cotas condominiais ingressadas como ação de cobrança caracterizariam a inadequação no procedimento. 
Entende Theodoro Junior, a favor da utilização de ambas as vias processuais:

As coisas, no entanto, não se passam de maneira tão singela. Primeiro, porque a existência de um título extrajudicial não torna indiscutível o negócio subjacente, de modo que o devedor conserva o direito de questioná-lo em juízo amplamente. Segundo, porque, estando a execução sujeita a requisitos específicos, pode o credor ver seu processo inviabilizado na via executiva, mesmo sendo titular do crédito ou a falta de algum requisito formal do título. Assim, cabe ao credor avaliar qual o caminho processual que se apresenta mais seguro para o exercício de sua pretensão. (THEODORO JUNIOR, 2016, p. 220).

Defende, assim, que a decisão deverá vir do credor, de modo que este se sinta mais seguro. Por outro lado, Neves acredita que essa liberalidade fere o princípio da economia processual, uma vez que no processo de conhecimento serão utilizados maiores recursos até que o credor detenha um título:

A criação de um título executivo judicial por meio de processo de conhecimento quando já existe título executivo extrajudicial em favor do autor demanda um trabalho jurisdicional inútil, ocupando o Poder Judiciário com um processo que não precisaria existir para tutelar o interesse da parte. A questão, portanto, não diz respeito à vontade do autor e à ausência de prejuízo ao réu, mas à perda de tempo, dinheiro e energia exigida do Poder Judiciário para criar um título executivo judicial reconhecendo uma obrigação já consagrada em título executivo extrajudicial. Trata-se de um verdadeiro atentado ao princípio da economia processual $^{2}$ sob seu aspecto macroscópico, permitindo-se um processo inútil por vontade das partes em detrimento do interesse público de se obterem mais resultados com menor atividade jurisdicional. (NEVES, 2016, p. 1.784).

Contudo, a questão pacificou-se com o julgado ora exposto:

[...] AÇÃO DE COBRANÇA. ENCARGOS CONDOMINIAIS. TÍTULO EXECUTIVO EXTRAJUDICIAL. AÇÃO DE CONHECIMENTO. PRERROGATIVA DA PARTE. ART. 785 DO CPC. SENTENÇA CASSADA. 1. $O$ artigo 785 do CPC dispõe que a existência de título executivo extrajudicial não é empecilho à opção da parte autora pelo processo de conhecimento, a fim de obter título executivo judicial. 2. Recurso provido. Sentença cassada. (Acórdão 1056490, 07069597820178070001, Relator: SEBASTIÃO COELHO,5a Turma Cível, data de julgamento: 25/10/2017, publicado no DJE: 9/11/2017. Pág.: Sem Página Cadastrada.). (grifo nosso).

2 Segundo Ada Pellegrini Grinover, o denominado princípio da economia processual preconiza o máximo resultado na atuação do direito com o mínimo emprego possível de atividades processuais. Esse é o princípio da simplificação ou princípio econômico. Princípio segundo o qual o processo deve obter o maior resultado com o mínimo de esforço 
Todavia, qual seja a via escolhida pelo credor, desde que detenha direito do recebimento do crédito, poderá recebê-lo, haja vista a regulamentação em norma processual, art. 785 do Código de Processo Civil de 2015.

\section{DO TÍTULO EXECUTIVO}

O título executivo é primordial para qualquer ação de execução, juntamente com a falta de adimplemento do devedor, explica Marcus Vinicius Rios Gonçalves:

O título executivo é a fonte da execução. Desde que surge, ganha vida própria, que independe da existência do crédito. Ele passa a ser o ato- chave que permite o desencadeamento da sanção estatal, sendo requisito ao mesmo tempo necessário e suficiente para a execução, que prescinde da prova da efetiva existência do crédito. (GONÇALVES, 2020, p. 72).

O título executivo é dividido em duas espécies: o título executivo judicial e o título executivo extrajudicial, sendo essencial a distinção entre ambos devido às diferentes formas de executá-los.

O título executivo judicial se dá por meio de sentença, quando há intervenção do Estado-Juiz. O título executivo extrajudicial por sua vez, se dá por vontade das partes, na esfera extrajudicial.

Assim entende Neves: o título executivo judicial é formado pelo juiz, por meio de atuação jurisdicional, enquanto o título executivo extrajudicial é formado por ato de vontade das partes envolvidas na relação jurídica de direito material. (NEVES, 2016, p. 1.848).

Apesar de o título executivo extrajudicial ser formado pela vontade das partes, todos os títulos são criados pela lei, não sendo possível que as partes criem os referidos títulos, confirmando ainda, Marcus Vinicius Rios Gonçalves:

Não há título que não esteja previsto em lei: o rol legal é numerus clausus ${ }^{3}$. Não basta a mera convenção entre as partes. A sanção executiva, possibilidade de o Estado invadir a esfera patrimonial do indivíduo e retirar à força bens do seu patrimônio para entregá-los ao credor, ou vendê-los e, com o produto, fazer o pagamento, só é atribuída, pela lei, a determinados títulos. Além dos previstos no Código de Processo Civil, há aqueles criados por leis especiais. (GONÇALVES, 2020, p. 74).

Isto quer dizer que as partes devem observar o rol dos títulos executivos criados em lei para que, se necessário e possível, possam acordar entre si em seus termos. "O sistema do Código é o da taxatividade dos títulos executivos, de modo que só se revestem dessa qualidade aqueles instituídos pela lei". (THEODORO JUNIOR, 2017 p. 448).

3 DICIO. Numerus clausus: número que não se altera e estabelece a quantidade de pessoas que estão aptas para serem admitidas ou aceitas num grupo; número limitado, número limite. Etimologia (origem de numerus clausus). Do latim numerus clausus, número fechado. Disponível em: https://www.dicio.com.br/numerus-clausus/ 
Os títulos executivos judiciais constam no rol do art. 515 e os títulos executivos extrajudiciais constam no rol do art. 784, do Código de Processo Civil/2015, composto por 12 incisos, dentre os quais aqueles que são objeto deste trabalho, a saber os incisos VIII e X.

Conforme explicado por Theodoro Junior, ao disposto no art. 771 do Novo CPC que o processo de execução é fonte subsidiária para o procedimento de cumprimento de sentença:

O processo de execução contém a disciplina da ação executiva própria para a satisfação dos direitos representados por títulos executivos extrajudiciais. Serve também de fonte normativa subsidiária para o procedimento do cumprimento da sentença. (THEODORO JUNIOR, 2017, p. 294).

Afirma Neves que:

O Código de Processo Civil de 1973 deu aos títulos executivos extrajudiciais a mesma eficácia executiva dos títulos judiciais de modo que todos são aptos a instaurar a execução, mantendo o mesmo critério no novo Código de Processo Civil de 2015. (NEVES, 2016, p. 1.873).

De modo que, com a existência do rol, para a execução de qualquer dos títulos é necessário que sejam observadas as peculiaridades de cada um.

Assim, de acordo com o art. 783 do CPC, a execução para a cobrança de crédito deverá ser em título de obrigação certa, líquida e exigível.

Explica Montenegro Filho que:

A execução recai sobre a obrigação, não sobre o título que a corporifica (o que é certo, líquido e exigível não é o título, mas a obrigação). A obrigação deve ser certa, ou seja, deve existir; deve ser líquida, referindo-se ao objeto da prestação (o que e o quanto deverão ser adimplidos); e deve ser exigível, sinônimo de vencida, no aspecto processual. (MONTENEGRO FILHO, 2018, p.585).

No tocante ao inciso VIII do art. 784 do CPC/2015, autoriza-se somente ajuizamento da ação executiva, que persegue os aluguéis, seus acessórios (condomínios não adimplidos), com devidas multas e moras.

A dívida de condomínio, além de conter respaldo no contrato locatício, de forma acessória, obtém a mesma força jurídica nos termos do inciso $\mathrm{X}$, artigo 784 do CPC/2015, qual anteriormente não era regido pelo CPC/1973. Ou seja, o Condomínio teve força de título executivo extrajudicial somente com a Lei 13.105/2015.

Portanto, para que condomínios com convenções formadas antes do novo CPC possuam a benesse de título executivo, os mesmos têm de promover assembleias gerais para que seja votada a alteração das convenções condominiais à benesse o inciso X, artigo 784 do CPC/2015.

A título de exemplo, em ambos os títulos (judicial ou extrajudicial), para que haja a devida execução, é necessário comprovar a existência da obrigação, por 
meio de contrato ou convenção condominial, sua liquidez, utilizando uma planilha de débito devidamente atualizada, e sua exigibilidade constando na planilha de débitos apenas as parcelas e cotas vencidas.

Respeitando o princípio do contraditório e da ampla defesa ${ }^{4}$, é que, mesmo em execução judicial, o devedor executado poderá se defender, seja pela impugnação ao cumprimento de sentença, nos incidentes de cumprimento de sentença do processo de conhecimento, ou por embargos à execução, nos casos de ação de execução.

De todo modo, quando o devedor não paga de forma voluntária o que cabe ao credor, é que ocorre a intervenção do Estado para que o direito do credor seja empregado. Denomina assim Theodoro Junior, a execução forçada:

\footnotetext{
Atua o Estado, na execução, como substituto, promovendo uma atividade que competia ao devedor exercer: a satisfação da prestação a que tem direito o credor. Somente quando o obrigado não cumpre voluntariamente a obrigação é que tem lugar a intervenção do órgão judicial executivo. (THEODORO JUNIOR, 2017, p. 296).
}

Assim, quando de nenhum modo o executado cumpre sua obrigação para com o exequente, aquele é "coagido" a quitar seus débitos.

Na vigência do Código de Processo Civil de 1973, o procedimento apropriado para a cobrança das cotas condominiais era previsto pelo art. 275, inciso II, alínea $b$, pelo procedimento sumário. Assim, a forma para cobrança das cotas condominiais era por meio de Ação de Cobrança, dividida em duas fases: (i) a de conhecimento e (ii) a execução do título - na primeira fase o devedor era citado para apresentar defesa, podendo contestar a validade, os valores e outros fatores referentes ao pedido do Condomínio/Autor, sendo de igual modo direito do autor manifestar a defesa do devedor, com posterior apresentação de provas, designação de audiência, até que seja prolatada a sentença, improcedente ou procedente.

Após a procedência da ação, o Réu poderia recorrer em outras instâncias e somente depois do trânsito em julgado da sentença é que o Autor obtinha o título executivo judicial, para, assim, iniciar a segunda fase: a execução do título a partir do Cumprimento de Sentença, que é poder executar o crédito que lhe era devido. Em outras palavras, somente neste momento é que o Condomínio poderia penhorar os bens do devedor, então denominado executado.

Com a vigência do novo CPC/2015, a cota condominial entrou no rol dos títulos executivos extrajudiciais de modo que os débitos condominiais podem ser executados sem precisar passar pela fase de conhecimento.

4 AMBITO JURIDICO: O princípio do contraditório e da ampla defesa, em Direito processual, é um princípio jurídico fundamental do processo judicial moderno. Exprime a garantia de que ninguém pode sofrer os efeitos de uma sentença sem ter tido a possibilidade de ser parte do processo do qual esta provém, ou seja, sem ter tido a possibilidade de uma efetiva participação na formação da decisão judicial (direito de defesa). O princípio é derivado da frase latina Audi alteram partem (ou audiatur et altera pars), que significa "ouvir o outro lado", ou "deixar o outro lado ser ouvido bem". Disponível em: https://ambitojuridico.com.br/cadernos/direito-administrativo/o-principio- constitucional-do-contraditorio-e-da-ampla-defesa-no-processo-administrativo-disciplinar/ 
O entendimento do CPC/1973 era de que a cobrança promovida pelo condomínio em face do condômino deveria ser por meio do processo de conhecimento, não podendo o condomínio executar o condômino, em especial em razão da inexistência de contrato escrito reconhecido pelo devedor quanto ao débito, não servindo para tanto somente convenção condominial. (NEVES, 2016).

A cota condominial só poderia ser executada se fosse encargo expressamente previsto no contrato de locação do apartamento. A inovação com a inclusão referente às contribuições ordinárias e extraordinárias tornou executável as cotas condominiais, resguardando os condôminos adimplentes, que pagam a mais para suprirem o inadimplemento do condômino devedor.

Na ação de execução de título extrajudicial discute-se apenas o título, e o mecanismo de defesa para o condômino devedor, ora executado é Embargos à Execução, a partir do qual se poderá discutir/alegar se o título é exigível, entre as outras possibilidades que contam do rol do art. 917, do CPC/2015.

No mesmo prazo para a apresentação de Embargos à Execução, o executado pode requerer o parcelamento do débito com uma entrada de $30 \%$ sobre o total do débito, e o remanescente em 06 parcelas mensais, corrigidas mensalmente, acrescido de juros de $1 \%$ ao mês, conforme dispõe o art. 916 do Código de Processo Civil e, uma vez requerido o parcelamento, o executado não poderá discutir quanto ao valor exequendo. (BRASIL, 2015, $\$ 6^{\circ}$ ), entendimento também pacificado pelos tribunais:

APELAÇÃO CÍVEL. EMBARGOS À EXECUÇÃO. SENTENÇA EXTINTIVA. OPÇÃO PELO PARCELAMENTO, ART. 916, $\S^{\circ}$ DO CPC, QUE IMPLICA NO RECONHECIMENTO DO VALOR DO DÉBITO. [...] Com efeito, denota-se do artigo 916 o CPC/15 que a adesão ao parcelamento do débito implica, consequentemente, no reconhecimento do crédito do exequente. 2 . Veja-se que, ao aderir ao pagamento parcelado do débito, a executada, além de reconhecer o crédito do exequente, renúncia (sic) tacitamente ao direito de opor embargos. Apelação conhecida e desprovida. (TJPR - 16a C. Cível - 001634797.2018.8.16.0021 - Cascavel - Rel.:Desembargador Paulo Cezar Bellio - J. 02.10.2019) (grifo nosso).

Sem que haja pagamento voluntário, proposta de parcelamento ou apresentação de Embargos à Execução, e tratando-se de execução por quantia certa, o Código de Processo Civil, no art. 824, diz que esta deverá ser feita por expropriação de bens do executado, ressalvadas as exceções especiais (BRASIL, 2015). Deverá seguir-se uma ordem de penhora no artigo 835 do Código de Processo Civil/2015, sendo de relevância para o presente trabalho os incisos I, IV, V, VI XII e XIII.

Deve-se dar prioridade para a penhora em dinheiro, podendo o juiz de ofício mudar a ordem conforme a circunstância de cada caso, observando ainda os bens que são passíveis ou não de penhora, conforme disposto no $\S 1^{\circ}$ do mesmo artigo.

A penhora é um dos métodos que podem ser utilizados para que a execução seja satisfeita e na ação de execução buscar-se-á em primeiro lugar a satisfação do crédito em espécie (dinheiro). Contudo não são em todos os casos que os executa- 
dos possuem determinados valores em dinheiro para a quitação de seus débitos, mas podem disponibilizar de bens passiveis de penhora, para que haja devida conversão e pagamento/satisfação em favor do credor exequente.

A penhora visa dar início, ou preparação, à transmissão forçada de bens do devedor, para apurar a quantia necessária ao pagamento do credor. Pressupõe, destarte, a responsabilidade patrimonial e a transmissibilidade dos bens. É o patrimônio do devedor (ou de alguém que tenha assumido responsabilidade pelo pagamento da dívida) que deve ser atingido pela penhora, nunca o de terceiros estranhos à obrigação ou à responsabilidade. (THEODORO JUNIOR, 2017 [p. 574]).

Assim explica Theodoro Junior que a penhora se trata de transmissão forçada de bens do devedor ou daquele que assumiu a responsabilidade pelo pagamento de uma dívida.

De forma clara, a penhora consiste na apreensão judicial dos bens do devedor com finalidade de garantir o pagamento de uma dívida, sendo os bens retirados da posse do devedor para garantir a execução do débito, entretanto não são todos os bens que podem ser penhoráveis. O CPC/2015 dispõe um rol de bens que não são penhoráveis; em outras palavras, são bens que não são passíveis de alienação e conversão do bem em valor econômico, que não pode ser atingido pela dívida do proprietário. - o que, na concepção de Caio Mario da Silva Pereira, é inconveniente, haja vista que a impenhorabilidade de determinados bens pode frustrar algumas execuções:

Impenhorabilidade importa em estabelecer que o bem gravado não pode
ser objeto de penhora por dívidas contraídas pelo seu titular. Embora ju-
ridicamente fundamentada, esta cláusula é socialmente inconveniente,
pela sua percussão nos direitos de terceiros. Questão controvertida, e
objeto de vivas polêmicas, foi se a inalienabilidade implica necessaria-
mente a impenhorabilidade. Num e noutro sentido alinham se juristas
de todos os portes, com boa sorte de argumentos, salientando-se que, se
o proprietário do bem gravado não o puder transferir por ato próprio
(porém lhe for permitido contrair dívidas pelas quais responda ele inde-
pendentemente do gravame), fácil será burlar a restrição. A matéria tem
sido debatida pelos nossos civilistas, seja em comentário à lei, seja em
obra de exposição sistemática. (PEREIRA, 2017, p.109).

A impenhorabilidade do bem de família é regida pela Lei 8.009/90 e sua função é exatamente essa: proteger o imóvel residencial da entidade familiar, de forma que o imóvel não responda pela dívida civil, comercial, fiscal, previdenciária, ou de outra natureza contraída pelos cônjuges ou pelos pais, ou pelos filhos que sejam proprietários e nele residam, salvo nas hipóteses previstas nesta lei, disposto em artigo $1^{\circ}$. (BRASIL, 1990).

Apesar da referida lei proteger os imóveis com caráter de bem familiar para que estes não respondam por dívidas, é válido observar que para evitar determinadas fraudes ou inadimplências, são resguardadas pela própria lei algumas exceções. 
O inciso IV do $\$ 1^{\circ}$ ressalta que em determinadas hipóteses, como, por exemplo, se a ação de execução for movida para cobrança de impostos, predial ou territorial, taxas e contribuições devidas em função do imóvel familiar, é possível que este seja penhorado.

Aqui temos uma questão que causa muita divergência, e eis o problema para os condôminos devedores, uma vez que diante de situações financeiras precárias, as cotas condominiais deixam de ser prioridade e muitos não entendem que seu patrimônio, seu lar, poderá ser atingido por sua dívida.

Quando se trata de dívida de condominial, diante de sua natureza e sua função social, o imóvel gerador dos débitos não é tratado como bem de família,

questão sobre a qual, apesar de pacificada, poucos possuem ciência e pode ser um fato gerador para a inadimplência condominial.

Ainda que o fator da dívida não seja devido ao inadimplemento de cotas condominiais, é aplicada a mesma regra para qualquer dívida gerada pelo apartamento. Exemplo no acórdão a seguir, em que o apartamento respondia por débito anterior à posse da nova proprietária, e estava em vias de leilão. A mesma alegou que era o único bem que possuía, e a dívida era anterior à sua posse, de modo que a unidade (o apartamento) não poderia ser leiloado.

[...] PENHORABILIDADE DO BEM DE FAMÍlIA. POSSIBILIDADE. LEI N. 8.009/1990, ART. $3^{\circ}$, IV. 1. Constitui obrigação de todo condômino concorrer para as despesas condominiais, na proporção de sua cota-parte, dada a natureza de comunidade singular do condomínio, centro de interesses comuns, que se sobrepõe ao interesse individual. 2. As despesas condominiais, inclusive as decorrentes de decisões judiciais, são obrigações propter rem, e por isso, será responsável pelo seu pagamento, na proporção de sua fração ideal, aquele que detém a qualidade de proprietário da unidade imobiliária ou seja titular de um dos aspectos da propriedade (posse, gozo, fruição), desde que tenha estabelecido relação jurídica direta com o condomínio, ainda que a dívida seja anterior a aquisição do imóvel. 3. Portanto, uma vez ajuizada a execução em face do condomínio, se inexiste patrimônio próprio para a satisfação do crédito, podem os condôminos ser chamados a responder pela dívida, na proporção de sua fração ideal. 4 . O bem residencial da família é penhorável para atender às despesas comuns de condomínio, que gozam de prevalência sobre interesses individuais de um condômino, nos termos da ressalva inserta na Lei n. 8.009/1990 (art. $3^{\circ}$, IV). 6. Recurso especial não provido. (STJ - Resp: 1473484 RS 2014/0185636-5, Relator: Ministro LUIS FELIPE SALOMÃO, Data de Julgamento: 21/06/2018, T4 - QUARTA TURMA, Data de Publicação: DJe 23/08/2018).(grifo nosso).

Diante das razões da Autora da ação, o ministro explica os motivos pelos quais o apartamento não é considerado bem de família, isto porque a dívida que levara o apartamento a leilão era composta pelo próprio condomínio, devendo a Autora arcar com sua cota-parte. 


\section{DAS DIVERGÊNCIAS NA APLICABILIDADE DO PROCESSAMEN- TO NA DÍVIDA PROPTER REM}

O CPC/2015 incluiu as despesas condominiais no rol dos títulos executivos extrajudiciais, artigo 784, inciso X, de modo a proteger os interesses doscondôminos prejudicados pelo inadimplemento de outro condômino. Entretanto, para que ocorra a efetiva execução desse título executivo extrajudicial, é necessário analisar muitos fatores, como os já expostos: a natureza da dívida, do título e sua aplicação.

Conforme já analisado, o condomínio possui natureza propter rem, o que significa que o proprietário/possuidor do imóvel responde por seus débitos, ainda que adquiridos anteriormente, como reforçado pelo o art. 1.345 do Código Civil.

Ainda que o bem esteja vinculado por garantia real ao pagamento do débito, entende Marcus Vinicius Rios Gonçalves:

Aquele que deu o bem em garantia real de uma dívida torna-se responsável, até o limite do valor do bem, pelo pagamento dela, ainda que não seja o devedor. A garantia real pode ser oferecida em razão de dívida própria ou de terceiro. Se for dada em garantia de dívida de terceiro, o titular do bem torna-se responsável pelo pagamento, respeitado o seu valor. (GONÇALVES, 2020, p. 59).

Assim podemos adiante analisar os julgados diante das diversas situações possíveis.

A priori, é fato que a execução de título executivo extrajudicial de condomínio se dá em face daquele que é proprietário/possuidor e, em necessidade de penhora judicial do imóvel em decorrência de dívida condominial, este é penhorável.

Isto exposto, é demonstrado de forma sucinta o procedimento e possíveis entendimentos acerca do assunto.

O Condomínio Exequente propõe a Ação de Título Executivo Extrajudicial em face do Condômino Executado, que é citado para pagamento do débito total em 03 dias, ou para que apresente embargos à execução em 15, conforme artigo 829, § $1^{\circ}$ e artigos 914 e 915, todos do CPC/2015.

Sem que o Executado quite o débito ou apresente embargos à execução (defesa) após devidamente citado, são iniciados os atos de penhora em face deste, sendo primeiro requerida a penhora nos ativos financeiros do executado junto aos bancos, por intermédio do sistema BACENJUD (convênio do Banco Central com o Poder Judiciário). Caso o retorno da referida pesquisa seja frutífera, o executado é intimado para se manifestar, conforme artigo $854, \S 2^{\circ}$, do CPC/2015, para que no prazo de 05 dias informe se a quantia penhorada é impenhorável, ou se há penhora excessiva; porém, se a penhora restar infrutífera, o exequente poderá apresentar outros bens à penhora.

Devido à natureza do crédito, os exequentes normalmente optam por requerer a penhora do imóvel, e assim pode o exequente deparar-se com diversas situações, as quais se passam a expor: 
Quando o imóvel devedor não possui registro do contrato de venda e compra e está sendo penhorado, aduz o Código Civil que o vendedor responde pelos débitos da coisa até o momento da tradição:

Art. 502. O vendedor, salvo convenção em contrário, responde por todos os débitos que gravem a coisa até o momento da tradição. (BRASIL, Código Civil, 2002).

Há decisões que seguem o que o Código Civil dispõe, conforme elencado, imputando ao novo adquirente o ônus de todos os débitos do imóvel, ainda que antes de sua aquisição, senão vejamos:

“[...] Em razão do insucesso da medida, o credor solicitou a penhora do apartamento objeto da ação, tendo em vista a natureza propter rem da obrigação. Ocorre que, conforme informado no início da demanda, os requeridos, apesar de figurarem no polo passivo, não constam como proprietários na matrícula do imóvel, pois alienaram a terceiros que figuram na matrícula, quais sejam MARILDA CARDOSO e CAROLINA CARDOSO ARAÚJO (fls. 1172/1177). No mais, como se sabe, a dívida oriunda de despesas condominiais tem natureza jurídica propter rem - da "própria coisa" -, de maneira que o próprio imóvel responde pelo débito, independentemente de quem seja o seu proprietário. Em outras palavras, não importa em nome de quem esteja registrado o bem perante o Registro Imobiliário, bem como se o atual proprietário participou da lide no polo passivo ou não, vez que obrigações dessa natureza vinculam a dívida à própria unidade condominial. [...]." (Processo n. 0016290-91.2016.8.26.0564, fls. 1178/1180, em tramite na $5^{\text {a }}$ vara cível de São Bernardo do Campo, Juiz de Direito Dr. Carlo Mazza Britto Melfi, disponibilizado no DJE em 25/04/2019.). (grifo nosso).

O caso supra trata-se de Ação de Cobrança em face somente dos proprietários registrados na matrícula do imóvel. Na fase de cumprimento de sentença, no momento do pedido de penhora do imóvel, as adquirentes do imóvel se manifestaram nos autos como interessadas, informando que a unidade devedora (apartamento) não poderia ser leiloada, vez que os executados não eram mais proprietários do imóvel, pois foi celebrado contrato de venda e compra sem o devido registro.

Assim, afirmou o Juiz que, devido à natureza da obrigação, não importava quem era o proprietário registrado, pois o próprio imóvel responde por seu débito. Nessa mesma esteira o julgado dos Embargos à Execução ao Título Executivo Extrajudicial:

CONDOMÍNIO. EMBARGOS À EXECUÇÃO. O fato de a obrigação propter rem se vincular ao imóvel tem como fundamento a sua preservação, não havendo sentido em se falar em crédito vinculado à unidade em virtude de relações existentes com os antigos proprietários. Sentença mantida. Recurso desprovido. (TJSP; Apelação Cível 101707124.2019.8.26.0554; Relator (a): Felipe Ferreira; Órgão Julgador: $26^{\mathrm{a}}$ Câ- 
mara de Direito Privado; Foro de Santo André - $5^{\text {a }}$ Vara Cível; Data do Julgamento: 13/05/2020; Data de Registro: 13/05/2020). (grifos nossos).

No entanto, há decisões em casos idênticos ou similares, que entendem que responde pelo débito condominial aquele que de fato consta como proprietário no registro do imóvel, de modo que, se não houve o devido registro, ainda que o vendedor do imóvel não resida mais nele, deverá arcar com as cotas condominiais inadimplidas pelo novo comprador, que não efetuou o devido registro do contrato na certidão do imóvel no cartório, conforme exposto:

TAXAS CONDOMINIAIS - ILEGITIMIDADE PASSIVA - NÃO OCORRENCIA - CASSAR A SENTENÇA - OBRIGAÇÃO PROPTER REM - RESPONSABILIDADE PELO PAGAMENTO - PROPRIETÁRIO DO IMÓVEL - CONTRATO DE COMPRA E VENDA - AUSENCIA DE REGISTRO E CIENCIA INEQUIVOCA DO AUTOR ACERCA DA TRANSAÇÃO - DESPESA CONDOMINIAL - DIVIDA “EX RE". - [...] Por se tratar de obrigação "propter rem", o pagamento da taxa condominial vincula o proprietário que consta no registro imobiliário - Não havendo ocorrido à averbação da compra e venda no registro do imóvel, nem mesmo a ciência do condomínio acerca da transação, os valores das taxas condominiais devem ser atribuídos ao proprietário constante do registro. (TJ-MG - AC: 10000190531749001 MG, Relator: Shirley Fenzi Bertão, Data de Julgamento: 01/07/2019, Dada de Publicação: 03/07/2019). (grifos nossos).]

Aqui temos a contradição entre dois julgados, em que um deles defende que, devido à natureza do débito, o próprio imóvel responde por ele, independente de quem conste no registro imobiliário. Outro entende que o registro faz diferença, devendo imputar responsabilidade àquele que configura no documento pertinente, ainda que já tenha vendido o imóvel.

Contudo, há decisões que entendem que o exequente pode escolher, que tanto o promitente vendedor quanto o promissário comprador respondem de forma solidária quanto ao débito condominial:

DESPESAS CONDOMINIAIS. IMÓVEL ALIENADO A TERCEIRO. AUSENCIA DE REGISTRO NO CARTÓRIO. CONDOMÍNIO NÃO CIENTIFICADO. RESPONSABILIDADE PELO PAGAMENTO DO PROPRIETÁRIO. De acordo com entendimento firmado em sede de recurso repetitivo (REsp 1.345.331/RS), nos casos de promessa de compra e venda, a responsabilidade pelo pagamento das despesas condominiais pode recair tanto sobre o promissário comprador quanto sobre o promitente vendedor, a depender do caso concreto, não bastando a mera imissão na posse do imóvel pelo comprador para que este seja a parte legítima em eventual cobrança das despesas condominiais. [...] 3 Apelação conhecida e não provida. (TJ-DF 07093402520188070001 DF 0709340- 25.2018.8.07.0001, Relator: FÁBIO EDUARDO MARQUES, Data de Julgamento: 22/04/2019, $7^{\text {a }}$ Turma Cível, Data de Publicação noDJE: 02/05/2019. Pág.: Sem Página Cadastrada.). (grifos nossos). 
Nesse momento, é evidente que os entendimentos podem ser diversos acerca do mesmo tema, de modo que pode ser responsabilizado o atual proprietário registrado na matrícula do imóvel pelos débitos anteriores à sua aquisição quanto aos débitos posteriores à venda.

Além da discussão quanto à efetividade da dívida Propter rem em relação ao registro da propriedade na matrícula do imóvel, há controvérsias com relação à responsabilidade do pagamento quando a compra foi feita por intermédio da construtora.

Muitas decisões defendem que o comprador não pode ser responsabilizado pelas cotas condominiais vencidas antes da posse no imóvel, configurada pela entrega das chaves, contudo, as construtoras em sua defesa aduzem que, de certo modo, elas também não migram na posse, além do contrato de compra e venda estipular que tal ônus, mesmo antes da entrega das chaves, deverá ser suportado pelo comprador, situação sobre a qual alguns julgadores discordam, conforme ora colacionado:

APELAÇÃO. DESPESAS CONDOMINIAIS. EMBARGOS À EXECUÇÃO. ADQUIRENTES DE IMÓVEL NOVO QUE JAMAIS FORAM IMITIDOS NA POSSE. OBRIGAÇÃO QUE SOMENTE NASCE COM A POSSIBILIDADE DE UTILIZAÇÃO DO BEM. RESPONSABILIDADE DA CONSTRUTORA PELAS DESPESAS CONDOMINIAIS. [...] "O que define a responsabilidade pelo pagamento das obrigações condominiais não é o registro do compromisso de compra e venda, mas a relação jurídica material com o imóvel, representada pela imissão na posse pelo promissário comprador e pela ciência inequívoca do condomínio acerca da transação". No caso, a responsabilidade pelo pagamento das despesas condominiais não pode ser carreada aos proprietários, pois a obrigação do adquirente nasce desde o dia em que recebe a posse direta do imóvel, já que a responsabilidade de custear as despesas de manutenção decorre da possibilidade de utilização do imóvel. Logo, tendo em vista a sua relação jurídica material com o imóvel (posse), a construtora (vendedora) deve responder pelos débitos condominiais ora executados. (TJSP; Apelação Cível 100864980.2018.8.26.0009; Relator (a): Adilson de Araujo; Órgão Julgador: $31^{\text {a }}$ Câmara de Direito Privado; Foro Regional IX - Vila Prudente - $3^{\text {a }}$ Vara Cível; Data do Julgamento: 06/05/2020; Data de Registro: 06/05/2020).

De tal modo, há julgadores que entendem que não há óbice ocorrer execução em face do comprador, ainda que os débitos sejam anteriores à sua posse, devido à natureza propter rem da obrigação. A fim de proteger sempre o interesse da coletividade, sendo certo o pagamento seja lá por quem for, e se entender no direito, ingressar com nova ação em face daquele que entende ser o real devedor, decidindo assim:

APELAÇÃO. DESPESAS CONDOMINIAIS. EMBARGOS À EXECUÇÃO. Sentença de procedência. Recurso do condomínio embargado. Incidência da execução sobre despesas condominiais vencidas anteriormente ao recebimento das chaves pelo compromissário comprador de unidade autônoma recém- construída. Responsabilidade do com- 
promissário comprador pelas despesas condominiais condicionada à imissão na posse do imóvel. Circunstância que, não obstante, há de ser cotejada à natureza propter rem da obrigação. Inteligência dos arts. 1.334, $\S 2^{\circ}$ e 1.345 do Código Civil. [...] Tutela do interesse prevalente da coletividade em receber os recursos para o pagamento das despesas indispensáveis e inadiáveis, podendo o credor escolher, entre aqueles que tenham relação jurídica vinculada ao imóvel, o que mais prontamente poderá cumprir a obrigação, ressalvado o direito regressivo contra o efetivo responsável. [...] Recurso parcialmente provido. (TJSP; Apelação Cível 1005388- 61.2017.8.26.0068; Relator (a): Airton Pinheiro de Castro; Órgão Julgador: $29^{\text {a }}$ Câmara de Direito Privado; Foro de Barueri - $3^{\text {a } V a r a ~ C i ́ v e l ; ~ D a t a ~ d o ~ J u l g a m e n t o: ~ 05 / 02 / 2014 ; ~ D a t a ~ d e ~ R e g i s t r o: ~}$ 14/05/2020). (grifos nossos).

Nesse diapasão, denota-se a insegurança que o credor pode sentir no momento do ajuizamento da ação, vez que podem surgir vários entendimentos quanto à demanda, insegurança inclusive, para o comprador, que muitas vezes não tem ciência da existência de débitos anteriores à posse, mesmo resguardado o direito em ação de regresso contra a construtora.

Entretanto, além das possibilidades elencadas, há a possibilidade de o imóvel devedor de despesas condominiais ser consolidado pelo banco fiduciante, devido à falta de pagamento da alienação fiduciária e entende que não deverá responder por débitos adquiridos anteriormente. Isto é, o comprador do imóvel, além de não pagar as cotas condominiais, deixou de pagar o financiamento, de modo que a CEF retoma para si bem imóvel outrora alienado.

Neste momento questiona-se se há possibilidade de penhora quando o imóvel é retomado pela instituição alienante, haja vista que em decisões judiciais é entendido que diante da retomada/consolidação do imóvel, a obrigação de quitar os débitos condominiais existentes é da CEF, devido à sua natureza:

[...] A obrigação da CEF tem natureza propter rem , cercando a unidade condominial, fazendo com que a dívida se transmita por inteiro ao novo proprietário, independentemente de quem a produziu ou do fato de não haver o adquirente participado da ação que reconheceu a dívida. [...] CONDOMÍNIO. DESPESAS. OBRIGAÇÃO ?PROPTER REM?. - $O$ adquirente de unidade condominial responde pelos encargos existentes junto ao condomínio, mesmo que anteriores à aquisição. Incidência da Súmula $n^{\circ}$ 83-STJ. Recurso especial não conhecido [...] Para garantir o equilíbrio econômico e financeiro do condomínio, a cota parte atribuível a cada unidade é considerada obrigação? propter rem?. Por isso, o arrematante de imóvel em condomínio responde pelas cotas condominiais em atraso, ainda que anteriores à aquisição. [...] Fixada a obrigação da empresa adquirente pelo débito já reconhecido em Juízo, não há falar-se em incompetência da Justiça Federal, dada a natureza jurídica da ora Excipiente, tampouco havendo falar-se em prescrição, pelos mesmos motivos já expostos. No que toca ao argumento de ilegitimidade passiva, colhe-se dos autos, pela exceção ora em análise, que tomou a CEF formal conhecimento do débito e 
pode formular a defesa cabível. Por fim, assentado o caráter propter rem da obrigação, que restou integralmente assumida pela CEF ao arrematar o imóvel, nisso incluindo-se não apenas a dívida propriamente dita mas os consectários acrescidos dela decorrentes. Posto isso, REJEITO a exceção de pré-executividade oposta pela CEF. Considerando que a manifestação da CEF obrigou à formulação de defesa por parte do condomínio exequente, pagará a empresa honorários advocatícios arbitrados em $10 \%$ do valor do débito atualizado. Intimem-se. (Justiça Federal de $1^{\circ}$ Grau. Cumprimento de Sentença: processo $n^{\circ} 5004092-$ 38.2019.4.03.6114).

Isto posto, é possível analisar que, apesar da forma de cobrança das cotas condominiais ter aparentemente se transformado em um procedimento célere para que haja a efetiva entrega da tutela jurisdicional, é necessário verificar vários requisitos, além do que dispõe o rol dos títulos executivos extrajudiciais e a natureza da dívida aduzida pelo Código Civil.

É necessário que seja verificado a quem de fato o título pertence, ainda que o dispositivo de lei e a doutrina afirmem que este não importa devido à natureza do débito. É necessário ainda verificar se o imóvel está alienado ou consolidado, informação essa que nem sempre é disponibilizada e atualizada no registro do imóvel.

Assim se faz presente, de forma prejudicial, a maneira que cada caso é entendido e julgado sobre a mesma coisa, deixando as partes inseguras com o que pode ocorrer em seu caso concreto.

Não obstante as diretrizes do Código Civil e do Código de Processo Civil, faz-se necessário o máximo de cuidado e busca de documentos antes do ingresso da ação.

\section{CONSIDERAÇÕES FINAIS}

A princípio o trabalho foi desenvolvido para averiguar e demonstrar as divergências de julgados no âmbito judicial sobre as mesmas questões e situações semelhantes. Apesar das peculiaridades entre as discussões de cada modalidade, seja com relação à penhora de imóvel alienado, ou sem registro formal no órgão competente, não há pacificações para cada caso.

Durante o desenvolvimento, compreendeu-se que, apesar das particularidades do crédito condominial, o imóvel sempre poderá ser levado a leilão, senão de forma integral, pelo menos os direitos aquisitivos sobre ele.

Ao início demonstrou-se os direitos, as especificidades do condomínio, a natureza de sua cobrança e a forma que se pode cobrar. São cediços os diversos julgados diante da demanda em razão da matéria, entretanto é importante resguardar os direitos envolvidos e pleiteados, para que nenhuma das partes seja prejudicada. Isso nos faz acreditar que não há segurança jurídica em termos de julgados e por mais cuidados que os patronos tomem ao ingressar com ações, o resultadoé imprevisível. Por fim, as divergências nas decisões judiciais acerca do explanado pelo Código Civil e pelo Código de Processo Civil, de modo que, se observadas todas as considerações dos doutrinadores e da legislação, a decisão no final se sobressai pelo entendimento individual do magistrado. 


\section{REFERENNCIAS}

BRASIL, Lei $\mathrm{n}^{\circ}$. 4.591, de 16 de setembro de 1964. Lei dos Condomínios. Dispõe sobre o condomínio em edificações e as incorporações imobiliárias. Disponível em: http://www. planalto.gov.br/ccivil_03/leis/14591.htm

BRASIL, Lei $n^{\circ}$. Lei 8.009, de 29 de março de 1990. Dispõe sobre a impenhorabilidade do bem de família. Disponível em: http:/ / www.planalto.gov.br/ccivil_03/leis/L8009.htm

BRASIL, Lei n. 10.406, de 10 de janeiro de 2002. Código Civil. Disponível em: http:// www.planalto.gov.br/ccivil_03/leis/2002/110406.htm

BRASIL, Lei no . 13.105, de 16 de março de 2015. Código de Processo Civil. Disponível em: http://www.planalto.gov.br/ccivil_03/_ato2015-2018/2015/lei/113105.htm

BRASIL. Superior Tribunal de Justiça. STJ - Resp: 1473484 RS 2014/0185636-5, Relator: Ministro LUIS FELIPE SALOMÃO, Data de Julgamento: 21/06/2018, T4 - QUARTA TURMA, Data de Publicação: DJe 23/08/2018.

BRASIL. Supremo Tribunal Federal. Súmula n. 478. Na Execução de crédito relativo a cotas condominiais, este tem preferência sobre o hipotecário. Disponível em: http:/ / www. coad.com.br/busca/detalhe_16/2408/Sumulas_e_enunciados

CASSETTARI, Christiano. Elementos de direito civil. 6 ed. São Paulo: Saraiva Educação. 2018.

DESIMONE, Mariana Ribeiro. Penalidades legais ao inadimplente do condomínio. Sindiconet, 2010. Disponível em: https://www.sindiconet.com.br/informese/penalidades-legais-ao-inadimplente-do- condominio-administracao-inadimplencia-em-condominios

DESIMONE, Mariana Ribeiro. Cobrança direta de inadimplentes, 2010. Disponível em: https://www.sindiconet.com.br/informese/cobranca-direta-de-inadimplentes- administracao-inadimplencia-em-condominios

DINIZ, Maria Helena. Curso de Direito Civil Brasileiro: Direito das Coisas. 23. Ed. vol. 4. São Paulo: Saraiva. 2008.

DIREITONET, Obrigação propter rem, 2013. Disponível em: https://www.direitonet.com. br/dicionario/exibir/1257/Obrigacao-propter-rem

DISTRITO FEDERAL. Tribunal de Justiça. TJ-DF 07093402520188070001, Relator: FÁBIO EDUARDO MARQUES, Data de Julgamento: 22/04/2019, $7^{\text {a }}$ Turma Cível, Data de Publicação no DJE: 02/05/2019. Pág.:

DUPLIQUE. A importância do pagamento em dia da taxa de condomínio, 2019. Disponível em: https://duplique.com.br/noticia/a-importancia-do-pagamento-em-dia- da-taxa-de-condominio

GOMES, Orlando. Direitos Reais. 19 ed. Atualizador. Luiz Edson Fachin. Rio de Janeiro: Forense. 2004. 
GONÇALVES, Carlos Roberto. Direito Civil Brasileiro: Direito das Coisas. $7^{\text {a }}$ Ed. vol. 5. São Paulo: Saraiva, 2012.

GONÇALVES, Carlos Roberto. Direito civil brasileiro, volume 5: direito das coisas. $13^{\text {a }}$ Ed. São Paulo: Saraiva Educação, 2018.

GONÇALVES, Marcus Vinicius Rios. Curso de direito processual civil. Vol. 3 Execução, processo de execução nos tribunais e meios de impugnação das decisões. $13^{a}$ Ed. São Paulo: Saraiva Educação, 2020. Disponível em: https:/ / books.google.com.br/books?id=vbfEDwAAQBAJ\&pg=PT77\&dq\#v=onepage\& $q \& f=$ false

MELLO, Cleyson de Moraes. Condomínio: doutrina, legislação, jurisprudência, peças processuais: modelos. Rio de Janeiro: Maria Augusta Delgado. 2012.

MELLO, Cleyson de Moraes. Direito Civil: Direito das Coisas. 2 ed. Rio de Janeiro. Maria Augusta Delgado. 2017.

MELO, Marco Aurélio Bezerra de. Condomínio de fato: Agoniza, mas não morre. GENJuridico, 2017. Disponível em: http://genjuridico.com.br/2017/11/29/condominio-de-fato-agoniza-mas-nao-morre/

MINAS GERAIS. Tribunal de Justiça: TJ-MG - AC: 10000190531749001 MG, Relator: Shirley Fenzi Bertão, Data de Julgamento: 01/07/2019, Dada de Publicação: 03/07/2019

MONTENEGRO FILHO, Misael. Novo Código de Processo Civil comentado. 3 ed. rev. e atual. São Paulo: Atlas. 2018.

NEVES, Daniel Amorim Assumpção. Manual de direito processual civil. Volume único. $8^{\mathrm{a}}$ ed. Salvador. Editora JusPodivm. 2016.

PEREIRA, Caio Mario da Silva. Instituições de direito civil. Vol. IV. 25 ed. Rio de Janeiro. Forense, 2017.

RIZZARDO, Arnaldo. Condomínio edilício e incorporação imobiliária. 5 ed. rev., atual. e ampl. Rio de Janeiro. Forense. 2017. Disponível em: https://tlgur.com/d/g2A7VrMG

SÃO PAULO. Justiça Federal de Primeiro Grau. Cumprimento de sentença. Processo 5004092-38.2019.4.03.6114. 26 de fevereiro de 2020. Publicado no DJe: 28/02/2020.

SÃO PAULO. Tribunal de Justiça. Acórdão 1056490, 07069597820178070001, Relator: SE-

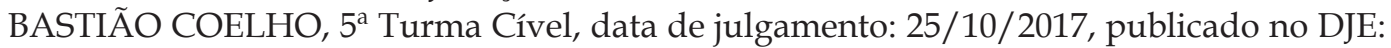
9/11/2017. Pág.: Sem Página Cadastrada.

SÃO PAULO. Tribunal de Justiça. TJSP; Apelação Cível 1007023- 74.2014.8.26.0006; Relator (a): AZUMA NISHI; Órgão Julgador: $37^{\mathrm{a}}$ Câmara Extraordinária de Direito Privado; Foro Regional VI - Penha de França - $4^{\text {a }}$ Vara Cível; Data do Julgamento: 05/02/2018; Data de Registro: 05/02/2018.

SÃO PAULO. Tribunal de Justiça. TJSP - Apelação Cível 1017997- 75.2015.8.26.0576; Relator (a): Bonilha Filho; Órgão Julgador: $26^{\text {a }}$ Câmara de Direito Privado; Foro de São José do Rio Preto - 4a Vara Cível; Data do Julgamento: 19/04/2018; Data de Registro: 19/04/2018. 
SÃO PAULO. Tribunal de Justiça: TJSP; Agravo de Instrumento 2098276- 08.2018.8.26.0000; Relator (a): Carlos Henrique Miguel Trevisan; Órgão Julgador: 29a Câmara de Direito Privado; Foro de Cotia - $1^{\text {a }}$ Vara Cível; Data do Julgamento: 05/02/2014; Data de Registro: 08/10/2018.

SÃO PAULO. Tribunal de Justiça. TJSP; Apelação Cível 1016810- 97.2017.8.26.0564; Relator (a): Francisco Occhiuto Júnior; Órgão Julgador: $32^{a}$ Câmara de Direito Privado; Foro de São Bernardo do Campo - $8^{a}$ Vara Cível; Data do Julgamento: 05/11/2018; Data de Registro: 05/11/2018.

SÃO PAULO. Tribunal de Justiça. Processo nº 0016290-91.2016.8.26.0564, fls. 1178/1180. $5^{\text {a }}$ vara cível de São Bernardo do Campo, Juiz de Direito Dr. Carlo Mazza Britto Melfi, disponibilizado no DJE em 25/04/2019.

SÃO PAULO. Tribunal de Justiça. TJPR - 16 ${ }^{a}$ C.Cível - 0016347-97.2018.8.16.0021 -Cascavel - Rel.: Desembargador Paulo Cezar Bellio - J. 02.10.2019.

SÃO PAULO. Tribunal de Justiça. TJSP; Apelação Cível 1008649- 80.2018.8.26.0009; Relator (a): Adilson de Araujo; Órgão Julgador: $31^{\text {a }}$ Câmara de Direito Privado; Foro Regional IX - Vila Prudente - $3^{\text {a }}$ Vara Cível; Data do Julgamento: 06/05/2020; Data de Registro: 06/05/2020.

SÃO PAULO. Tribunal de Justiça. TJSP - Apelação Cível 1015733- 12.2019.8.26.0361; Relator (a): Campos Petroni; Órgão Julgador: $27^{\mathrm{a}}$ Câmara de Direito Privado; Foro de Mogi das Cruzes - $2^{\mathrm{a}}$ Vara Cível; Data do Julgamento: 07/05/2020; Data de Registro: 07/05/2020.

SÃO PAULO. Tribunal de Justiça. TJSP; Apelação Cível 1017071- 24.2019.8.26.0554; Relator (a): Felipe Ferreira; Órgão Julgador: $26^{a}$ Câmara de Direito Privado; Foro de Santo André $5^{a}$ Vara Cível; Data do Julgamento: 13/05/2020; Data de Registro: 13/05/2020.

SÃO PAULO. Tribunal de Justiça. TJSP; Apelação Cível 1005388- 61.2017.8.26.0068; Relator (a): Airton Pinheiro de Castro; Órgão Julgador: $29^{a}$ Câmara de Direito Privado; Foro de Barueri - $3^{\mathrm{a}}$ Vara Cível; Data do Julgamento: 05/02/2014; Data de Registro: 14/05/ 2020.

STANGORLINI,2018, pág.27. STANGORLINI, Aline Regina Alves. Direito Condominial e as Execuções. Revista da Puc-SP. ed 2. 2018.

TARTUCE, Flávio. Direito Civil: Direito das Coisas - vol. 4. 11. Ed. Rio de Janeiro: Forense, 2019.

TARTUCE, Flávio. Manual de Direito Civil: volume único. 8 ed. rev, atual e ampl. Rio de Janeiro: Forense. São Paulo: Método, 2018.

THEODORO JÚNIOR, Humberto. Curso de Direito Processual Civil: Execução forçada, processo nos tribunais, recursos e direito intertemporal. 48. ed. Rio de Janeiro: Forense, 2016.

THEODORO JUNIOR, Humberto. Curso de Direito Processual Civil. Vol. III. 50 ${ }^{\mathrm{a}}$ Ed. rev., atual. e ampl. Rio de Janeiro. Forense. 2017.

TOWNSQ, Inadimplência em condomínio: como lidar com esse problema?, 2019. Disponível em: https:/ / blog.townsq.com.br/inadimplencia-em-condominio/ 
TUDOCONDO, Como cobrarcondomínio atrasado? Disponível em: https://tudocondo. com.br/como-cobrar-condominio-atrasado

VIEIRA, Brenda. Introdução ao Direito das Coisas. Artigo. Jus, 2015. Disponível em: https://jus.com.br/artigos/41012/introducao-ao-direito-das-coisas

\section{AGRADECIMENTOS}

A Deus, sempre. Por me sustentar e guiar nos dias difíceis e escuros. Por fazer o extraordinário na minha vida.

A meu filho Miguel, que é o meu raio de sol, a luz dos meus olhos e minha maior motivação.

À professora Daniela Pozza Batista, que esteve firme comigo nesta jornada, de forma essencial para o meu aprendizado acadêmico, profissional e pessoal.

À professora Aline Regina Alves Stangorlini e à professora Elaine Cristina Saraiva Bentivoglio, pela atenção e dedicação ao realizarem a leitura do trabalho, demaneira memorável. Obrigada pela oportunidade.

Sou eternamente grata por tanto. (Pamella Karoline Gomes) 